\title{
Failure to Detect Superoxide in Human Neutrophils Stimulated With Latex Particles ${ }^{(21)}$
}

\author{
JOHN T. CURNUTTE AND ALFRED I. TAUBER ${ }^{(26)}$ \\ Department of Hematology and Oncology, Children's Hospital Medical Center and the Department of Pediatrics, \\ Harvard Medical School, Boston, Massachusetts [J.T.C.] and William B. Castle Hematology Research Laboratories, \\ Boston City Hospital and the Departments of Medicine and Biochemistry, Boston University School of Medicine, \\ Boston, Massachusetts, USA [A.I.T.]
}

\begin{abstract}
Summary
Human neutrophils stimulated with either latex particles or opsonized zymosan exhibited equivalent rates of net oxygen consumption as well as hydrogen peroxide release. The quantity of superoxide $\left(\mathrm{O}_{2}{ }^{-}\right)$detected in latex-stimulated neutrophils was less than $2 \%$ of that seen with opsonized zymosan stimulation, and only several-fold greater than that of resting cells. The failure to detect $\mathrm{O}_{2}{ }^{-}$in the latex-stimulated neutrophils was due neither to latex acting as a $\mathrm{O}_{2}{ }^{-}$scavenger nor to its interference with the $\mathrm{O}_{2}{ }^{-}$ forming system of the neutrophil. An intracellular site of $\mathrm{O}_{2}{ }^{-}$ generation could not be demonstrated. NADPH oxidase activity in cells exposed to latex particles was only $10 \%$ of that seen in cells comparably activated with opsonized zymosan. Latex particles have the unusual property of stimulating the respiratory burst of the human neutrophil without the extracellular release of $\mathrm{O}_{2}{ }^{-}$. The potential physiologic importance of this finding is discussed.
\end{abstract}

\section{Abbreviations}

$\mathrm{O}_{2}^{-}$, superoxide

$\mathrm{O}_{2}$, oxygen

$\mathrm{H}_{2} \mathrm{O}_{2}$, hydrogen peroxide

SOD, superoxide dismutase

PBS, phosphate buffered saline

PBS $^{-}$, phosphate-buffered saline without $\mathrm{Ca}^{++}$and $\mathrm{Mg}^{++}$

HEPES, $N$-2-hydroxyethyl piperazine- $N^{\prime}$-2-'ethanesulfonic acid

Superoxide production is an integral component of the respiratory burst that occurs in human neutrophils when exposed to a variety of phagocytosable particles or other soluble stimuli $(4,7)$. In the first report that neutrophils generate $\mathrm{O}_{2}{ }^{-}$, Babior, et al. (1) found that neutrophils phagocytizing latex particles exhibited a modest, but statistically significant, increase in $\mathrm{O}_{2}{ }^{-}$production. Subsequent reports, however, have indicated that other phagocytosable particles stimulate $\mathrm{O}_{2}{ }^{-}$production in quantities much larger than that observed with latex (7). This finding suggested that either latex particles were a relatively weak stimulus of the respiratory burst as a whole, or that $\mathrm{O}_{2}{ }^{-}$production was selectively dissociated from other components of the respiratory burst. The results presented below indicate that latex particles are, in fact, a potent stimulus for the respiratory burst, but that only small amounts of $\mathrm{O}_{2}^{-}$are detected.

\section{MATERIALS AND METHODS}

Materials. Ferricytochrome $c$ (Type VI), zymosan, superoxide dismutase $(2900 \mathrm{U} / \mathrm{mg})$, xanthine oxidase, and purine were obtained from Sigma Chemical Co., St. Louis, MO. Polystyrene/ toluene particles $(2.77 \mu \mathrm{m}$ diameter) were purchased from Dow Chemical Corp., Midland, MI. Macrodex (dextran 70) $(6 \%$ in $0.9 \%$ $\mathrm{NaCl}$ ) and Hypaque-Ficoll (Ficoll-Paque) were purchased from Pharmacia, Piscataway, NJ. All other reagents were the highest quality commercially available and were used without further purification.

Preparation of neutrophils and phagocytosable particles. Neutrophils were harvested from fresh human blood obtained from normal adult donors by the dextran-sedimentation method previously described (8). After hypotonic lysis of contaminating erythrocytes, the neutrophils were further purified by centrifugation over Hypaque-Ficoll (17), which yielded a greater than 99\% pure preparation. Zymosan particles were opsonized with fresh autologous human serum just before use by the method of Hohn and Lehrer (11) and then suspended in PBS at a concentration of $60 \mathrm{mg} / \mathrm{ml}\left(4.56 \times 10^{9}\right.$ particles $\left./ \mathrm{ml}\right)$. Latex particles were dialyzed three times against 1 liter $0.9 \% \mathrm{NaCl}$ at $8^{\circ} \mathrm{C}$ for a total of $48 \mathrm{~h}$, and then stored at $4^{\circ} \mathrm{C}$ in suspension in $0.9 \% \mathrm{NaCl}$ at a concentration of $3.0 \times 10^{9}$ particles $/ \mathrm{ml}$.

Determination of neutrophil oxygen consumption, $\mathrm{O}_{2}{ }^{-}$production, and $\mathrm{H}_{2} \mathrm{O}_{2}$ generation. Oxygen consumption was measured using a Model 53 Biological Oxygen Monitor (Yellow Springs Instrument Co., Yellow Springs, OH) calibrated using the phenylhydrazine oxidation method (13). Before the start of each determination, 0.1 $\mathrm{ml}$ cell suspension was added to $2.9 \mathrm{ml}$ PBS (containing $1 \mathrm{mM}$ sodium azide and $7.5 \mathrm{mM}$ glucose, prewarmed to $37^{\circ} \mathrm{C}$ ) in a siliconized sample chamber equipped with a magnetic stirrer and allowed to equilibrate for 2 min. Oxygen consumption during phagocytosis was determined by introducing $0.1 \mathrm{ml}$ of prewarmed particle suspension into the sample chamber. Preliminary experiments showed that maximal oxygen consumption occurred with final particle concentrations of $10^{8}$ particles $/ \mathrm{ml}$ for the latex beads and $1.5 \times 10^{8}$ particles $/ \mathrm{ml}$ for opsonized zymosan. Using optimal concentrations of particles, the maximal rate of $\mathrm{O}_{2}$ consumption was linear over at least a 10 -fold range of neutrophil concentrations $\left(1.6-16 \times 10^{6}\right.$ cells $\left./ \mathrm{ml}\right)$. Based on these results, all oxygen consumption assays were performed with $6.6 \times 10^{6}$ cells $/ \mathrm{ml}$. Azide did not affect the rate of $\mathrm{O}_{2}$ consumption.

Superoxide production was determined concurrently with $\mathrm{O}_{2}$ consumption by the method of Curnutte and Babior (8) using two additional sample chambers with magnetic stirrers. Each of the two reaction mixtures contained cytochrome $c(120 \mu \mathrm{M})$, neutrophils $\left(0.5 \times 10^{6}\right.$ cells $/ \mathrm{ml}$ for opsonized zymosan studies and $5 \times$ $10^{6}$ cells $/ \mathrm{ml}$ for latex particles), sodium azide $(0.7 \mathrm{mM})$, and phagocytosable particles at the concentrations listed above for $\mathrm{O}_{2}$ consumption assays. One reaction mixture contained SOD $(20 \mu \mathrm{g} /$ $\mathrm{ml})$. The rate of $\mathrm{O}_{2}{ }^{-}$production was linear over a cell concentration range of $0.5-21 \times 10^{6} \mathrm{cells} / \mathrm{ml}$. Azide did not affect the rate of $\mathrm{O}_{2}{ }^{-}$generation.

$\mathrm{H}_{2} \mathrm{O}_{2}$ production was determined by modification of the thiocyanate method of Thurman et al. (18). Reaction mixtures were identical to those used in $\mathrm{O}_{2}$ consumption studies except that the neutrophil concentration was $1.5 \times 10^{7}$ cells $/ \mathrm{ml}$ (the assay was linear with cell concentration between $0.5-1.5 \times 10^{7}$ cells $/ \mathrm{ml}$ ). The reaction was terminated after 4-min incubation by placing a 1.0-cc aliquot on ice and adding $0.2 \mathrm{ml} 80 \%(\mathrm{w} / \mathrm{v})$ trichloroacetic acid. Samples were spun at $2000 \times g$ for $5 \mathrm{~min}$ and $300 \mu \mathrm{l}$ of 
supernatant was assayed and compared to a standard curve of $\mathrm{H}_{2} \mathrm{O}_{2}$.

Determination of $\mathrm{O}_{2}^{-}$production by neutrophil subcellular 27,000 $\times g$ particles. Neutrophils $\left(5 \times 10^{8}\right)$ were preincubated in $2.9 \mathrm{ml}$ $\mathrm{PBS}$ at $37^{\circ} \mathrm{C}$ for $3 \mathrm{~min}$ in vials containing magnetic stirrers. Each reaction was started by adding $0.1 \mathrm{ml}$ of PBS, opsonized zymosan suspension as described above for oxygen consumption, or latex particles and terminated after 3 min by adding an equal volume of ice cold PBS to the reaction mixture and placing it on ice. The cells were then sonicated and fractionated by previously published methods (17) to obtain the $27,000 \times g$ particulate fraction, which was then assayed for $\mathrm{O}_{2}{ }^{-}$production by the cytochrome $c$ assay (12) in a Perkin-Elmer Model 552 double beam spectrophotometer. In experiments where the $27,000 \times g$ particles were solubilized by detergent, Triton X-100 (0.4\%) and FAD $(0.2 \mathrm{mM})$ were present in the $\mathrm{O}_{2}^{-}$assay curvettes as previously described $(9,12)$.

\section{RESULTS}

Figure 1 (top panel) shows a comparison of the time courses of $\mathrm{O}_{2}$ consumption and $\mathrm{O}_{2}{ }^{-}$production by neutrophils at rest and stimulated with opsonized zymosan. Both measurements were performed in parallel under similar conditions on cells from a single donor in order to permit direct comparisons. Resting cells in this experiment consumed little oxygen $\left(0.3 \mathrm{nmole} / \mathrm{min} / 10^{7}\right.$ cells) and produced $\mathrm{O}_{2}{ }^{-}$at a rate less than $1 \mathrm{nmole} / \mathrm{min} / 10^{7}$ cells. In cells exposed to opsonized zymosan, dramatic increases in both
$\mathrm{O}_{2}$ consumption and $\mathrm{O}_{2}^{-}$production were observed with rates that were several hundred-fold greater than those observed for resting cells. Superoxide production began $10 \mathrm{sec}$ after the addition of zymosan, reached its maximum rate for $40 \mathrm{sec}$, and then remained linear for approximately $4 \mathrm{~min}$, after which time the rate slowly decreased. The diminished rate of $\mathrm{O}_{2}^{-}$production was not due to the exhaustion of oxidized cytochrome $c$ in the reactioin mixture because doubling the concentration of cytochrome $c$ did not influence the detection of $\mathrm{O}_{2}{ }^{-}$. The time course for $\mathrm{O}_{2}$ consumption was parallel to that observed for $\mathrm{O}_{2}^{-}$generation (22).

In marked contrast to the results with opsonized zymosan are those results obtained using comparably sized latex particles (Fig. 1 , lower panel). Although the measured $\mathrm{O}_{2}$ consumption was increased nearly as much as with zymosan, only $1 \%$ as much $\mathrm{O}_{2}{ }^{-}$ was detected (Table 1) (23). Attempts to recover more $\mathrm{O}_{2}^{-}$by doubling the cytochrome $c$ concentration or extending the duration of incubation were unsuccessful. Even though little $\mathrm{O}_{2}{ }^{-}$was detected in latex-stimulated neutrophils, one of the other products of the respiratory burst, $\mathrm{H}_{2} \mathrm{O}_{2}$, was readily measurable. As shown in Table $1,30 \%( \pm 4 \%$ S.D.) of the oxygen consumed was recovered as $\mathrm{H}_{2} \mathrm{O}_{2}$ in the case of latex, whereas $52 \%$ ( $\pm 5 \%$ S.D.) was recovered when zymosan was the stimulus. These values are in excellent agreement with previously reported recoveries of $\mathrm{H}_{2} \mathrm{O}_{2}$ (e.g., Table VIII in reference 15).

The data in Figure 1 and Table 1 show that in the presence of opsonized zymosan, neutrophils generate nearly two moles of $\mathrm{O}_{2}{ }^{-}$ for each mole of $\mathrm{O}_{2}$ consumed. This stoichiometry is found

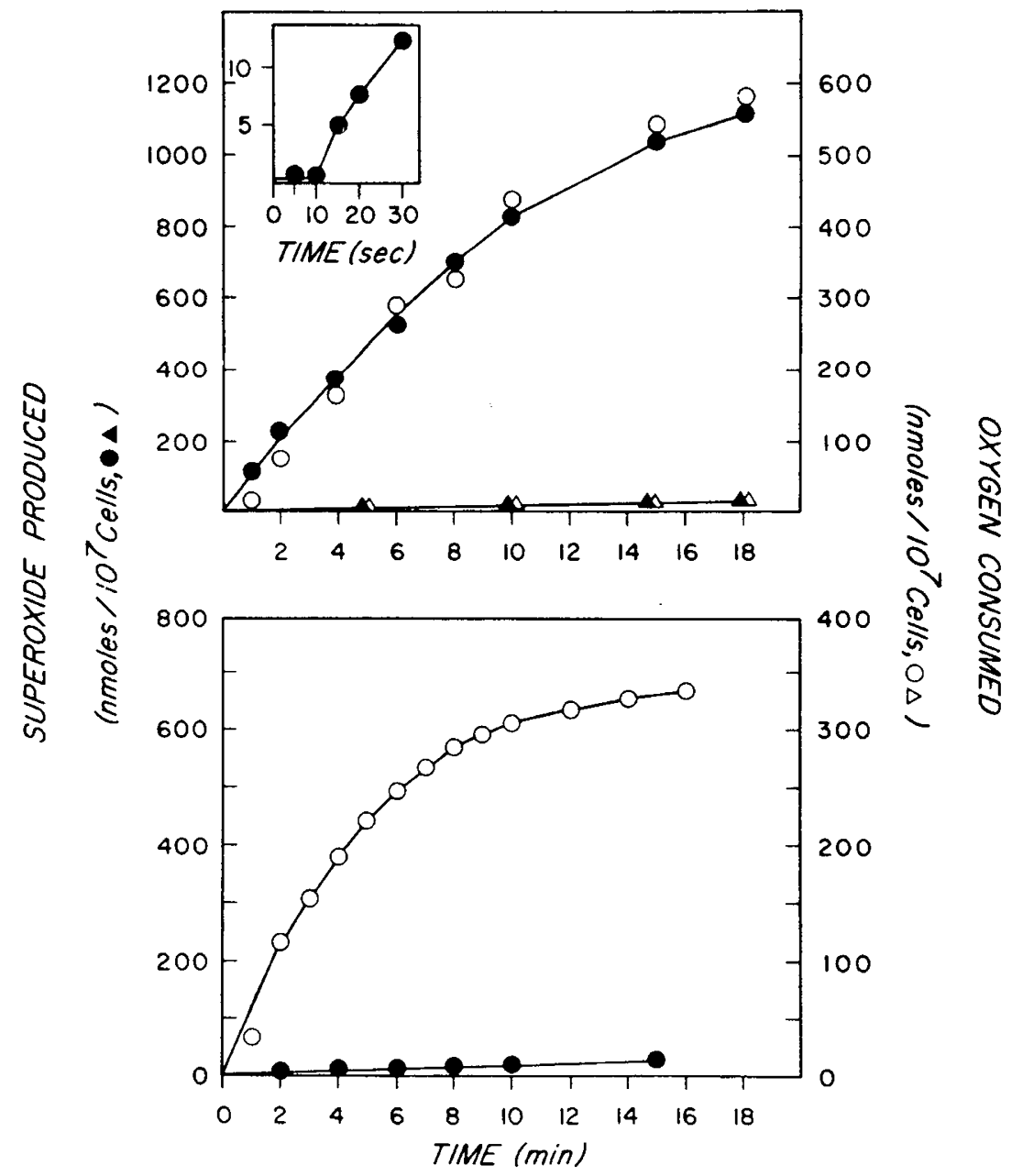

Fig. 1. Oxygen consumption and $\mathrm{O}_{2}{ }^{-}$production by resting and stimulated cells. Oxygen consumption and $\mathrm{O}_{2}{ }^{-}$production were determined as described in "Materials and Methods." The experiment was performed with three different preparations of cells: $(O, \triangle)$, oxygen consumption and $(\bullet$, $\Delta), \mathrm{O}_{2}^{-}$production. The figure shows a representative experiment. Top panel: triangles, resting cells and circles, opsonized zymosan-stimulated cells. Inset: higher resolution time course of $\mathrm{O}_{2}^{-}$production with opsonized zymosan as stimulus (cell concentration $7 \times 10^{6}$ cells $/ \mathrm{ml}$ ). Bottom panel: latex particles as stimulus. 
Table 1. Comparison of the respiratory bursts of human neutrophils stimulated with either opsonized zymosan or latex particles (nmole/4 $\mathrm{min} / 10^{7}$ cells) ${ }^{1}$

\begin{tabular}{lccc}
\hline Stimulus & $\begin{array}{c}\text { Oxygen } \\
\text { consumed }\end{array}$ & $\begin{array}{c}\mathrm{O}_{2}^{-} \\
\text {produced }\end{array}$ & $\begin{array}{c}\mathrm{H}_{2} \mathrm{O}_{2} \\
\text { produced }\end{array}$ \\
\hline None & $1.0 \pm 0.4$ & $0.6 \pm 0.2$ & 0 \\
Zymosan & $229.6 \pm 18.2$ & $420.0 \pm 29.7$ & $119.0 \pm 11.6$ \\
Latex & $169.0 \pm 16.0$ & $2.8 \pm 2.8$ & $50.3 \pm 6.5$ \\
\hline
\end{tabular}

${ }^{1}$ Oxygen consumption, $\mathrm{O}_{2}^{-}$production, and $\mathrm{H}_{2} \mathrm{O}_{2}$ production were determined as described in "Materials and Methods." The data represent the mean \pm S.E. from three different preparations of cells. The values in the table reflect the amounts of oxygen consumed, $\mathrm{O}_{2}{ }^{-}$produced, or $\mathrm{H}_{2} \mathrm{O}_{2}$ produced during the first $4 \mathrm{~min}$ of the reaction.

because the oxygen electrode used in these experiments measures only net oxygen consumption and is unable to detect that portion of oxygen which is first consumed and then later recycled back to oxygen (2). At least several reactions known to occur in the neutrophil can recycle oxygen, most notably the dismutation of $\mathrm{O}_{2}{ }^{-}$and the breakdown of $\mathrm{H}_{2} \mathrm{O}_{2}$ by catalase:

$$
\begin{gathered}
2 \mathrm{O}_{2}{ }^{-}+2 \mathrm{H}^{+} \rightarrow \mathrm{H}_{2} \mathrm{O}_{2}+\mathrm{O}_{2} \\
2 \mathrm{H}_{2} \mathrm{O}_{2} \rightarrow 2 \mathrm{H}_{2} \mathrm{O}+\mathrm{O}_{2}
\end{gathered}
$$

At present it is not possible to correct for all the recycling reactions and arrive at an accurate gross oxygen consumption; however, the observation here that $183 \%$ of the net oxygen consumed is recovered as $\mathrm{O}_{2}^{-}$suggests that $\mathrm{O}_{2}^{-}$is the major product of the respiratory burst in zymosan-stimulated cells and that a substantial portion of the $\mathrm{O}_{2}^{-}$, can be detected under our assay conditions. Because the latex-stimulated neutrophils are assayed under the same conditions, it is unlikely that the low rates of $\mathrm{O}_{2}{ }^{-}$production in these cells are a reflection of a failure to detect $\mathrm{O}_{2}{ }^{-}$. This matter is explored further in experiments described below.

The phenomenon of oxygen recycling raises an important issue regarding the latex data in Table 1 . If the latex-stimulated cells in fact do not produce $\mathrm{O}_{2}^{-}$(and the catalatic breakdown of $\mathrm{H}_{2} \mathrm{O}_{2}$ is blocked by azide in the medium), then little oxygen recycling should occur and the measured oxygen uptake of $169 \mathrm{nmol} / 4$ $\mathrm{min} / 10^{7}$ cells should approximate the true oxygen consumption. With zymosan, however, there should be appreciable recycling of oxygen. If all the $\mathrm{O}_{2}{ }^{-}$produced by the zymosan cell undergoes spontaneous dismutation by reaction (a), then 210 nmoles of oxygen will be recycled and not reflected in the measured net oxygen consumption. The gross oxygen uptake would then be estimated at $440 \mathrm{nmoles} \mathrm{O}_{2} / \mathrm{min} / 10^{7}$ cells $\left(229.6 \mathrm{nmoles} \mathrm{O}_{2} / \mathrm{min} /\right.$ $10^{7}$ cells measured, plus 210 nmoles $\mathrm{O}_{2} / \mathrm{min} / 10^{7}$ cells presumed recycled from $\mathrm{O}_{2}{ }^{-}$); thus, oxygen uptake in the latex-treated cells is only $38 \%$ of that seen with zymosan-stimulated neutrophils. This calculation helps explain why the measured rate of $\mathrm{H}_{2} \mathrm{O}_{2}$ production with latex in Table 1 is only $42 \%$ of that observed with zymosan. When corrected for the difference in the magnitudes of the respiratory bursts (assuming that little $\mathrm{O}_{2}{ }^{-}$is made by latex cells), the rates of $\mathrm{H}_{2} \mathrm{O}_{2}$ production with both stimuli are equivalent. As commented above, however, there are other reactions by which $\mathrm{O}_{2}{ }^{-}$could be metabolized and thus affect these calculations. For example, an oxidized molecule in the cell $\left(\mathrm{X}^{\text {ox }}\right)$ could be reduced by $\mathrm{O}_{2}^{-}$in the following reaction:

$$
\mathrm{O}_{2}{ }^{-}+\mathrm{X}^{\mathrm{ox}} \rightarrow 0_{2}+\mathrm{X}^{\mathrm{red}}
$$

The contribution of this type of reaction must be minor, given the close agreement of the $\mathrm{H}_{2} \mathrm{O}_{2}$ recoveries.

A control experiment was performed to assure that the observed difference in $\mathrm{O}_{2}^{-}$production between latex- and zymosan-stimulated cells in Table 1 was not due to the greater than 2 -fold difference in the magnitudes of the respiratory bursts. The concentration of opsonized zymosan was decreased to $0.4 \mathrm{mg} / \mathrm{ml}$, resulting in a drop in the rate of oxygen consumption $(22.4 \pm 2.3$ nmoles $\mathrm{O}_{2} / \mathrm{min} / 10^{7}$ cells) to a level which, after correcting for recycling of oxygen, was equal to that observed with latex (40.6 $\pm 3.6 \mathrm{nmoles} \mathrm{O}_{2} / \mathrm{min} / 10^{7}$ cells). Under these conditions, the rate of $\mathrm{O}_{2}{ }^{-}$production with latex was still less than $5 \%$ of that seen with zymosan as the stimulus $\left(36.1 \pm 2.3\right.$ nmoles $\mathrm{O}_{2}{ }^{-} / \mathrm{min} / 10^{7}$ cells).

One possible explanation for the low rate of $\mathrm{O}_{2}^{-}$production by latex-stimulated cells is that latex may function as a $\mathrm{O}_{2}{ }^{-}$scavenger, thus preventing the detection of $\mathrm{O}_{2}{ }^{-}$by the cytochrome $c$ assay. To test this possibility, the effect of latex particles on the detection of $\mathrm{O}_{2}{ }^{-}$produced by xanthine oxidase and purine, a known $\mathrm{O}_{2}{ }^{-}-$ generating system, was examined. At rates of $\mathrm{O}_{2}^{-}$generation equivalent to those seen in stimulated neutrophils, the ability of cytochrome $c(80 \mu \mathrm{M})$ to measure $\mathrm{O}_{2}^{-}$was totally unaffected by the presence of latex particles (data not shown). Another possible explanation is that superoxide dismutase might be released from latex-stimulated cells and thereby interfere with $\mathrm{O}_{2}{ }^{-}$detection. To test this possibility, opsonized zymosan was added to latex-stimulated cells either $10 \mathrm{sec}$ or $4 \mathrm{~min}$ after the latex was added. In neither case was there any change in the recovery of $\mathrm{O}_{2}^{-}$produced as a result of the zymosan stimulation (data not shown) (24). If there was an appreciable amount of SOD activity present in the incubation medium to interfere with $\mathrm{O}_{2}^{-}$detection in the latex case, then it should have affected the zymosan experiment in a like manner. Yet another possibility to explain the data is that latex damages the $\mathrm{O}_{2}^{-}$-generating system in the neutrophil. This, however, is also unlikely because, in the experiments in which zymosan was added to latex-stimulated cells, $\mathrm{O}_{2}^{-}$generation commenced after the addition of zymosan without a lag and at a rate which was the same as if the latex had never been present. If latex particles were inhibiting the $\mathrm{O}_{2}{ }^{-}$-forming system, then some diminution of $\mathrm{O}_{2}^{-}$production should have been observed when zymosan was added $4 \mathrm{~min}$ after the addition of latex.

The $27,000 \times g$ particulate fraction from activated human neutrophils is known to contain an NADPH-dependent $\mathrm{O}_{2}{ }^{-}$-generating system (12). We examined this fraction prepared from cells stimulated with opsonized zymosan or latex particles to determine whether the differences observed on the whole cell level also applied to this subcellular fraction. The particulate fraction from zymosan-stimulated cells produced $14.1 \pm 7.9$ S.E. nmoles $\mathrm{O}_{2}{ }^{-} /$ $\mathrm{min} / \mathrm{mg}$ protein $(n=3)$. In marked contrast, the same fraction obtained from cells stimulated with latex particles generated only $1.4 \pm 0.5$ S.E. nmoles $\mathrm{O}_{2}^{-} / \mathrm{min} / \mathrm{mg}$ protein.

The addition of detergent to the $27,000 \times g$ particulate preparation augments the $\mathrm{O}_{2}^{-}$-generating capacity of this cell-free system (12). We confirmed that the addition of a Triton X-100 $(0.4 \%)$ and $\mathrm{FAD}(0.2 \mathrm{mM})$ increased $\mathrm{O}_{2}^{-}$production by particles from zymosan-activated neutrophils $230 \pm 25 \%$ (mean \pm S.D., $n=3$ ) as compared to the same untreated $27,000 \times$ g particles. Particulate preparation from latex-stimulated cells showed a similar proportionate increase in $\mathrm{O}_{2}^{-}$-generating activity, $290 \pm 45.2 \%$. This augmented activity in the latex-stimulated preparation still did not account for the widely discrepant $\mathrm{O}_{2}{ }^{-}$rates seen in the corresponding intact cells.

\section{DISCUSSION}

Under conditions in which opsonized zymosan and latex comparably stimulate $\mathrm{O}_{2}$ uptake as well as $\mathrm{H}_{2} \mathrm{O}_{2}$ release in human neutrophils, $\mathrm{O}_{2}{ }^{-}$generation by latex-stimulated cells is only $2 \%$ of that observed with zymosan stimulation. This difference in $\mathrm{O}_{2}{ }^{-}$ detected is not due to latex particles either scavenging $\mathrm{O}_{2}{ }^{-}$or interfering with the $\mathrm{O}_{2}^{-}$-generating system of this cell.

In quantitative terms, the levels of $\mathrm{O}_{2}^{-}$produced by latexstimulated cells in this study are in accord with previously published reports $(1,19)$. Our results differ from those of Weening et al. (20) and Segal and Meshulam (16) who found substantial $\mathrm{O}_{2}{ }^{-}$ production in neutrophils activated with serum-treated or IgGcoated latex particles, in contrast to the unmodified latex particles employed in this study. It is likely that the coated latex particles had surface properties which enabled them to stimulate $\mathrm{O}_{2}{ }^{-}$ production. 
An intracellular site of $\mathrm{O}_{2}^{-}$production is an unlikely explanation for the observed low levels of $\mathrm{O}_{2}{ }^{-}$production in latex-stimulated cells for several reasons. First, the $\mathrm{O}_{2}{ }^{-}$assay employed in these experiments is highly efficient. In the case of zymosanstimulated cells, $183 \%$ of the net oxygen consumed was recovered as $\mathrm{O}_{2}{ }^{-}$(Table 1 ). This stoichiometry was consistent throughout the entire time course of the incubation (Fig. 1). In contrast, less than $2 \%$ of the $\mathrm{O}_{2}$ consumed by latex-stimulated cells was detected as $\mathrm{O}_{2}{ }^{-}$under identical experimental conditions. The high recovery of $\mathrm{O}_{2}^{-}$in the zymosan-stimulated cells suggests that under the assay conditions employed, a substantial portion of the $\mathrm{O}_{2}^{-}$generated can be detected. Second, cytochemical studies by Briggs $e t$ al. $(5,6)$, using cerium precipitation as a method for localizing $\mathrm{H}_{2} \mathrm{O}_{2}$ demonstrated that both zymosan- and latex-stimulated human neutrophils have $\mathrm{H}_{2} \mathrm{O}_{2}$ present both around phagocytic vacuoles and on the plasma membrane. Control experiments in these studies showed that the surface-bound reaction product did not result from the diffusion of $\mathrm{H}_{2} \mathrm{O}_{2}$ from within the cell. These results suggest that an oxidase activity is present on the plasma membrane of latex-stimulated human neutrophils and that if this oxidase generates $\mathrm{O}_{2}^{-}$, this anion should be detectable with the cytochrome $c$ assay employed in our experiments. Finally, the NADPH-dependent superoxide generating system in the 27,000 $\times g$ particulate fraction of zymosan-treated cells exhibited little activity when prepared from neutrophils stimulated with latex particles.

Taken together, the above arguments suggest that little or no $\mathrm{O}_{2}{ }^{-}$is produced at intracellular sites within latex-stimulated neutrophils; however, this possibility cannot be definitely excluded and remains speculative. Intracellular $\mathrm{O}_{2}{ }^{-}$generation has not been measured, because no such assay is sufficiently sensitive to measure the levels of $\mathrm{O}_{2}^{-}$believed to be present within neutrophils.

The experiments herein demonstrate that latex particles have the unusual property of markedly stimulating the respiratory burst without causing the release of extracellular $\mathrm{O}_{2}{ }^{-}$. In this regard, the latex particle is a unique respiratory burst stimulus (7). Although the failure to release $\mathrm{O}_{2}^{-}$into the extracellular medium may be a property peculiar to latex-stimulated neutrophils, it is also possible that it may represent a more general property of the phagocyte. The nature of the ingested particle may determine whether $\mathrm{O}_{2}{ }^{-}$is released into the extracellular medium or simply confined to the phagolysosome (or possibly, not made at all). This property would have potentially important implications in inflammation. The toxicity of a latex-like stimulus may well differ from a potent $\mathrm{O}_{2}{ }^{-}$ generating agonist with resultant changes in damage to host tissue or pathogens. The search for physiologic stimuli, which activate the respiratory burst as a latex particle, is underway to further explore these questions.

We regard at least two models as possible explanations for a respiratory burst without $\mathrm{O}_{2}^{-}$production. In the first, a single enzyme is responsible for both $\mathrm{O}_{2}^{-}$and $\mathrm{H}_{2} \mathrm{O}_{2}$ production, but the relative quantities of each produced is determined by the physical state of the enzyme. The precedent for this model is xanthine oxidase $(10,14)$, an enzyme which generates $\mathrm{O}_{2}{ }^{-}$and $\mathrm{H}_{2} \mathrm{O}_{2}$. The relative amounts of $\mathrm{O}_{2}^{-}$and $\mathrm{H}_{2} \mathrm{O}_{2}$ produced is determined by the reductive state of xanthine oxidase $-\mathrm{H}_{2} \mathrm{O}_{2}$ favored in the higher reductive state. Of interest in this regard are the data with $\mathrm{NADH}$ oxidase from guinea pig neutrophils (3). Both $\mathrm{O}_{2}{ }^{-}$and $\mathrm{H}_{2} \mathrm{O}_{2}$ are produced by this enzyme. Approximately $15 \%$ of the electrons derived from NADH are channeled into the univalent reduction of oxygen to $\mathrm{O}_{2}{ }^{-}$whereas the rest of the electrons are apparently donated to oxygen in pairs to form $\mathrm{H}_{2} \mathrm{O}_{2}$. At present it is not known whether the relative quantities of $\mathrm{O}_{2}{ }^{-}$and $\mathrm{H}_{2} \mathrm{O}_{2}$ can be experimentally controlled. In the second model, the enzyme which produces $\mathrm{O}_{2}^{-}$during the respiratory burst is distinct from an enzyme which produces $\mathrm{H}_{2} \mathrm{O}_{2}$ exclusively. With this model, the latex stimulation only triggers the latter enzyme, whereas with zymosan stimulation, both enzymes are activated.

\section{REFERENCES AND NOTES}

1. Babior, B. M., Kipnes, R. S., and Curnutte, J. T.: Biological defense mechanisms The production by leukocytes of superoxide, a potential bactericidal agent. $J$. Clin. Invest., 52: 741 (1973).

2. Badwey, J. A., Curnutte, J. T., and Karnovsky, M. L.: The enzyme of granulocytes that produces superoxide and peroxide. An elusive pimpernel. N. Eng. J. Med., 300: 1157 (1979)

3. Badwey, J. A. and Karnovsky, M. L.: Production of superoxide and hydrogen peroxide by an NADH-oxidase in guinea pig polymorphonuclear leukocytes. Modulation by nucleotides and divalent cations. J. Biol. Chem., 254: 11530 (1979).

4. Badwey, J. A. and Karnovsky, M. L.: Active oxygen species and the functions of phagocytic leukocytes. Ann. Rev. Biochem., 49: 695 (1980).

5. Briggs, R. T., Drath, D. B., Karnovsky, M. L., and Karnovsky, M. J.: Localization of the NADH-oxidase on the surface of human polymorphonuclear leukocytes by a new cytochemical method. J. Cell. Biol., 67: 566 (1975).

6. Briggs, R. T., Karnovsky, M. L., and Karnovsky, M. J.: Hydrogen peroxide production in chronic granulomatous disease: a new cytochemical study of reduced pyridine nucleotide oxidase. J. Clin. Invest., 59: 1088 (1977).

7. Cheson, B. D., Curnutte, J. T., and Babior, B. M.: The oxidative killing mechanisms of the neutrophil. Prog. Clin. Immunol., 3: 1 (1977).

8. Curnutte, J. T. and Babior, B. M.: Biological defense mechanisms: the effect of bacteria and serum on superoxide production by granulocytes. J. Clin. Invest., 53: 1662 (1974).

9. Gabig, T. G. and Babior, B. M.: The $\mathrm{O}_{2}{ }^{-}$-forming oxidase responsible for the respiratory burst in human neutrophils. Properties of the solubilized enzyme. J. Biol. Chem., 254: 9070 (1979).

10. Heuvelen, A. V.: Electron transport in xanthine oxidase. Biophys. J., 16: 939 (1976).

11. Hohn, D. G. and Lehrer, R. I.: NADPH-oxidase deficiency in X-linked chronic granulomatous disease. J. Clin. Invest., 55: 707 (1975)

12. Light, D. R., Walsh, C., O'Callaghan, A. M., Goetzl, E. J., and Tauber, A. I. Characteristics of the cofactor requirements for the superoxide-generating NADPH oxidase of human polymorphonuclear leukocytes. Biochemistry, 20 : 1468 (1981).

13. Misra, H. P. and Fridovich, I.: A convenient calibration of the Clark oxygen electrode. Anal. Biochem., 70: 632 (1979).

14. Olson, J. S., Ballou, D. P., Palmer, G., and Massey, V.: The mechanism of action of xanthine oxidase. J. Biol. Chem., 249: 4363 (1974).

15. Root, R. K. and Metcalf, J. A.: $\mathrm{H}_{2} \mathrm{O}_{2}$ release from human granulocytes during phagocytosis: relationship to superoxide anion formation and cellular catabolism of $\mathrm{H}_{2} \mathrm{O}_{2}$ : studies with normal and cytochalasin $\mathrm{B}$ treated cells. J. Clin. Invest., 60: 1266 (1977).

16. Segal, A. W. and Meshulam, T.: Production of superoxide by neutrophils: a reappraisal. FEBS Lett., I00: 27 (1979).

17. Tauber, A. I. and Goetzl, E. J.: Structural and catalytic properties of the solubilized superoxide generating activity of human polymorphonuclear leukocytes. Solubilization, stabilization in solution, and partial characterization. Biochemistry, 18: 5576 (1979).

18. Thurman, R. G., Ley, H. G., and Scholz, R.: Hepatic microsomal ethanol oxidation. Hydrogen peroxide formation and the role of catalase. Eur. $J$ Biochem, 25: 420 (1972).

19. Tsan, M. F. and McIntyre, P. A.: The requirement for membrane sialic acid in the stimulation of superoxide production during phagocytosis by human polymorphonuclear leukocytes. J. Exp. Med., 143: 1308 (1976)

20. Weening, R. S., Wever, R., and Roos, D.: Quantitative aspects of the production of superoxide radicals by phagocytizing human granulocytes. J. Lab. Clin. Med., 85: 245 (1975)

21. This work has previously been published in preliminary form: Blood, 52: 128 (1978).

22. For technical reasons related to the delay in re-equilibration of the oxygen electrode after the addition of opsonized zymosan, values for $\mathrm{O}_{2}$ consumption could not be accurately obtained during the first minute.

23. In contrast to unopsonized latex particles (as used in these experiments), unopsonized zymosan neither increases oxygen consumption nor $\mathrm{O}_{2}^{-}$generation over resting values.

24. The effects of zymosan and latex on oxygen consumption were not additive: the rate of oxygen consumption with both stimuli present was the same as with zymosan alone.

25. The authors wish to thank Drs. B. Babior, J., Badwey and M. L. Karnovsky for their constructive criticism and advice.

26. Requests for reprints should be addressed to: Dr. Alfred I. Tauber, Hematology Section, FGH Building, Boston City Hospital, 818 Harrison Ave., Boston, MA 02118.

27. This work was supported by Grants AI-15I16 and AI-18175 from the National Institutes of Health.

28. Received for publication May 7, 1982

29. Accepted for publication August 16, 1982 